\title{
CHAPTER I. GENERAL INTRODUCTION
}

$\begin{array}{ll}\text { 1. General Introduction } & 15\end{array}$

$\begin{array}{lll}1.1 & \text { General aspects of bacteriophages } & 15\end{array}$

$\begin{array}{lll}\text { 1.1.1 Historical context of bacteriophages } & 15\end{array}$

$\begin{array}{lll}\text { 1.1.2 Characteristics of bacteriophages } & 16\end{array}$

$\begin{array}{lll}\text { 1.1.3 } & \text { Bacteriophages nomenclature } & 19\end{array}$

$\begin{array}{lll}\text { 1.1.4 Isolation, identification and characterisation } & 21\end{array}$

$\begin{array}{lll}\text { 1.1.4.1 } & \text { Bacteriophages isolation } & 21\end{array}$

1.1.4.2 Bacteriophages identification and characterisation 23

$\begin{array}{lll}1.2 & \text { Bacteriophage therapy } & 24\end{array}$

$\begin{array}{lll}\text { 1.2.1 Phage therapy approaches } & 24\end{array}$

$\begin{array}{lll}\text { 1.2.2 } & \text { Bacteriophage encapsulation } & 25\end{array}$

$\begin{array}{ll}\text { 1.2.3 } & \text { Bacteriophage therapy resistance } \\ \end{array}$

1.3 Bacteriophage therapy against Salmonella 26

1.3.1 Salmonella epidemiology in humans 26

$\begin{array}{lll}\text { 1.3.1.1 Clinical aspects } & 28\end{array}$

1.3.1.2 Salmonellosis treatment in humans 28

1.3.2 Phage therapy in humans 29

1.3.2.1 Salmonella epidemiology in poultry production 29

1.3.2.2 Main sources of Salmonella contamination in the poultry sector 30

1.3.2.3 Main control measures for Salmonella in the poultry sector 32

1.3.2.4 Phage therapy against Salmonella in the poultry sector 33

$\begin{array}{lll}1.4 & \text { Study cornerstone } & 33\end{array}$

$\begin{array}{lll}1.5 & \text { References } & 35\end{array}$ 
$\begin{array}{lll}2 . & \text { Objectives }\end{array}$

CHAPTER III. EXPERIMENTAL CHAPTERS 49

3. Experimental chapters 51

3.1 Serovar bacteriophage diversity according to Salmonella serovar in 51 layer and broiler poultry farms

$\begin{array}{lll}3.1 .1 & \text { Abstract } & 52\end{array}$

3.1.2 Introduction 53

3.1.3 Material and Methods $\quad 54$

$\begin{array}{lll}3.1 .4 & \text { Results } & 56\end{array}$

$\begin{array}{lll}3.1 .5 & \text { Discussion } & 59\end{array}$

$\begin{array}{lll}\text { 3.1.6 References } & 61\end{array}$

3.2 Salmonella Infantis and Salmonella Enteritidis specific bacteriophages $\quad 67$ isolated from poultry faeces as a complementary tool for cleaning and disinfection against Salmonella

$\begin{array}{lll}3.2 .1 & \text { Abstract } & 68\end{array}$

$\begin{array}{lll}3.2 .2 & \text { Introduction } & 69\end{array}$

$\begin{array}{lll}\text { 3.2.3 Material and Methods } & 70\end{array}$

$\begin{array}{lll}3.2 .4 & \text { Results } & 75\end{array}$

$\begin{array}{llr}3.2 .5 & \text { Discussion } & 80\end{array}$

$\begin{array}{llr}\text { 3.2.6 References } & 82\end{array}$

3.3 Autophage as a control measure for Salmonella in laying hens $\quad 87$

$\begin{array}{llr}\text { 3.3.1 } & \text { Abstract } & 88\end{array}$

$\begin{array}{llr}\text { 3.3.2 Introduction } & 89\end{array}$

$\begin{array}{lll}\text { 3.3.3 Material and Methods } & 90\end{array}$

$\begin{array}{lll}\text { 3.3.4 Results } & 95\end{array}$

$\begin{array}{lll}\text { 3.3.5 Discussion } & 97\end{array}$ 
$\begin{array}{lll}\text { 3.3.6 References } & 99\end{array}$

$\begin{array}{ll}\text { CHAPTER IV. GENERAL DISCUSSION } & 105\end{array}$

$\begin{array}{ll}\text { 4. General Discussion } & 107\end{array}$

$\begin{array}{lll}4.1 & \text { References } & 111\end{array}$

$\begin{array}{ll}\text { CHAPTER V. CONCLUSIONS } & 113\end{array}$

$\begin{array}{ll}\text { 5. Conclusions } & 115\end{array}$ 